\title{
PENINGKATAN KREATIVITAS DAN HASIL BELAJAR PPKn MELALUI MODEL PROJECT BASED LEARNING DI KELAS VIII.2 SMPN 3 KOTO BARU
}

\author{
YENITA ANWAR \\ SMPN 3 Koto Baru, Dharmasraya \\ Email: yenitaanwarppkn@gmail.com
}

\begin{abstract}
This research is a Classroom Action Research (CAR) with the aim of enhancing the creativity and learning outcomes of Class VIII.2 PPKn at SMPN 3 Koto Baru by using the Project Based Learning learning model. The study was conducted in two cycles, each cycle consisting of two meetings. As a data collection tool is an observation sheet and the results of student scores from tests given at the end of cycle I and the end of cycle II, the results obtained about the creativity of students at the initial observation only $38.5 \%$ of students who are creative, in cycle I increased by 64 , $3 \%$ whereas in cycle II it increased again to $84.8 \%$. For learning outcomes of $23.1 \%$ of students who achieved KKM in pre-cycle, increased 46,2\% in cycle I and increased again to $76.9 \%$ in cycle II. This shows that the Project Based Learning learning model can be used as an alternative learning to increase student creativity and learning outcomes.
\end{abstract}

Keywords: creativity, learning outcomes, Project Based Learning models

\begin{abstract}
Abstrak: Penelitian ini merupakan Penelitian Tindakan Kelas (PTK) dengan tujuan meningkatkan kreativitas dan hasil belajar PPKn kelas VIII.2 SMPN 3 Koto Baru dengan menggunakan model pembelajaran Project Based Learning. Penelitian dilakukan dalam dua siklus, masing-masing siklus terdiri dari dua kali pertemuan. Sebagai alat pengumpul data adalah lembar observasi dan hasil nilai siswa dari tes yang diberikan pada akhir siklus I dan akhir siklus II, Hasil penelitian yang diperoleh mengenai kreativitas siswa pada pengamatan awal hanya 38,5 \% orang siswa yang kreativ, pada siklus I meningkat $64,3 \%$ sedangkan pada siklus II meningkat lagi menjadi 84,8\% .Untuk hasil belajar dari $23,1 \%$ siswa yang mencapai KKM pada pra siklus, meningkat $46,2 \%$ pada siklus I dan meningkat lagi menjadi $76,9 \%$ pada siklus II. Hal ini menunjukkan bahwa model pembelajaran Project Based Learning dapat dijadikan sebagai pembelajaran alternatif untuk meningkatkan kreativitas dan hasil belajar siswa.
\end{abstract}

Kata kunci : kreativitas, hasil belajar,model Project Based Learning

\section{A. Pendahuluan}

Berdasarkan Peraturan Menteri No. 58 Tahun 2014 tentang Kurikulum 2013, secara umum tujuan mata pelajaran Pendidikan Pancasila dan Kewarganegaraan pada jenjang pendidikan dasar dan menengah adalah mengembangkan potensi peserta didik dalam seluruh dimensi kewarganegaraan, yakni: (1) sikap kewarganegaraan termasuk keteguhan, komitmen dan tanggung jawab kewarganegaraan (civic confidence, civic committment, and civic responsibility); (2) pengetahuan kewarganegaraan; (3) keterampilan kewarganegaraan termasuk kecakapan dan partisipasi kewarganegaraan (civic competence and civic responsibility).

Titik sentral yang harus dicapai setiap kegiatan belajar mengajar adalah tercapainya tujuan pengajaran. Apapun yang termasuk perangkat program pengajaran 
dituntut secara mutlak untuk menunjang tercapainya tujuan. Guru tidak dibenarkan mengajar dengan kemalasan. Anak didikpun diwajibkan mempunyai kreativitas yang tinggi dalam belajar, bukan selalu menanti perintah guru. Kedua unsur manusiawi ini juga beraktivitas tidak lain karena ingin mencapai tujuan secara efektif dan efisien.

Pada dasarnya setiap guru mempunyai keinginan untuk dapat mengajar yang sebaik-baiknya, menyajikan pembelajaran dengan media yang mendukung dan berharap siswa-siswa dapat memahami setiap pelajaran yang disajikan serta mendapatkan hasil ujian yang maksimal. Tapi untuk mencapai tujuan yang mulia itu tidaklah mudah. Guna mencapai keinginan yang diinginkan tersebut, diperlukan tenaga, energi dan kemampuan untuk mempengaruhi orang lain, khususnya siswa. Kathy Paterson (2006) yang dikutip dalam PTK Nur Azizah (2009:1) menuliskan"Guru yang baik dan terampil memiliki sifat-sifat serta kemampuan mempengaruhi yang ada di dalam dirinya dan memanfaatkannya dengan memadukan sifat-sifat serta kemampuan tersebut dengan strategi pengajaran yang tepat. Mereka betul-betul ingin mencari cara yang terbaik, dan menggunakan kemampuan mereka itu demi kepentingan anak didiknya".

Guru sebagai pendidik dituntut untuk memiliki banyak kompetensi untuk menghadapi prilaku siswa-siswanya selama proses pembelajaran terjadi, termasuk yang dihadapi oleh penulis di kelas VIII 2 SMPN 3 Koto Baru, dimana siswa harus mengikuti pembelajaran PPKn yang notabenenya banyak hafalan ,pemahaman dan penjelasan- penjelasan dari guru pada jam-jam terakhir pelajaran, sehingga siswa merasa bosan dan terpaksa mengikuti pembelajaran disaat mereka menginginkan istirahat, mengakibatkan beberapa siswa memilih untuk tidur di kelas atau keluar ruangan. Dari hal tersebut, dapat memaklumi jika hasil belajar yang mereka dapatkan belum memenuhi kriteria ketuntasan, dari 26 siswa hanya siswa 10 yang mendapatkan nilai di atas 70. Nilai rata-rata 50, sedangkan kriteria ketuntasan minimal adalah 70 .

Selain hal tersebut di atas, penulis melihat ternyata beberapa siswa mengalami kesulitan dalam memahami penjelasan-penjelasan guru dan hafalan, ini terbukti dari hasil quiz 10 soal materi proses pembentukan peraturan perundang-undangan ternyata hanya $20 \%$ hasil jawaban siswa yang benar. Ketika penulis mengulangnya lagi pada minggu berikutnya, hasilnya tidak jauh berbeda. Menghadapi hal tersebut di atas, penulis mempunyai ide atau gagasan untuk mengkreativkan siswa dengan menggunakan model pembelajaran project based learning/penugasan proyek yang berkaitan dengan proses pembentukan peraturan perundang-undangan disesuaikan dengan Kompe-tensi Inti dan Kompetensi Dasar pada mata pelajaran PPKn di kelas tersebut.

Penulis memperkirakan dengan menggunakan penugasan proyek pada pembelajaran PPKn menjadikan pembelajaran PPKn di waktu akhir jam pelajaran tidak lagi menjadi pembelajaran yang membosankan dan dapat meningkatkan kemampuan, pemahaman dan kreativitas siswa pada pembelajaran PPKn. Dengan menyadari gejala-gejala atau kenyataan tersebut di atas, maka dalam penelitian ini penulis mengambil judul "Peningkatan kreativitas dan hasil belajar PPKn melalui model Project Based Learning Pada Siswa Kelas VIII 2 SMPN 3 Koto Baru"

Berdasarkan latar belakang yang telah dikemukakan di atas, maka masalah pokok dalam penelitian tindakan kelas ini dapat dirumuskan sebagai berikut: 1) Bagaimanakah peningkatan kreativitas belajar PPKn dengan diterapkannya Model Project Based Learning Pada Siswa Kelas VIII 2 SMPN 3 Koto Baru? 2) Bagaimanakah pengaruh pembelajaran Project Based Learning terhadap hasil belajar PPKn Pada Siswa Kelas VIII 2 SMPN 3 Koto Baru ? 


\section{B. Metodologi Penelitian}

Jenis penelitian ini adalah Penelitian Tindakan Kelas (Classroom Action Research) dengan empat tahapan, yaitu perencanaan, pelaksanaan, pengamatan, dan refleksi secara berkelanjutan dan bersiklus. Penelitian dilaksanakan di kelas VIII.2 SMPN 3 Koto Baru Kabupaten Dharmasraya. Adapun subjek pada penelitian adalah ini adalah siswa-siswi kelas VIII 2 SMPN 3 Koto Baru Kabupaten Dharmasraya yang berjumlah 26 orang, terdiri dari 11 laki-laki dan 14 orang perempuan. Penelitian ini diadakan pada semester ganjil tahun ajaran 2014/2015. Objek penelitian adalah pembelajaran PPKn untuk melihat peningkatan kreativitas dan hasil belajar siswa melalui model Project Based Learning.

Instrumen pengumpulan data dalam penelitian ini terdiri dari: 1) Observasi, pengumpulan data dengan observasi kreativitas siswa, yaitu untuk memperoleh informasi bagaimana pembelajaran PPKn dengan menerapkan model pembelajaran project based learning, yang diobservasi pada penelitian ini adalah bagaimana peningkatan kreativitas siswa dalam mengerjakan proyek/tugas yang diberikan .(lampiran 3 siklus I dan lampiran 4 siklus II). 2) Tes, tes yang diberikan bertujuan untuk melihat hasil belajar siswa pada aspek kognitif . Tes tersebut terdiri dari soalsoal dalam bentuk essay. Dalam penyusunan tes tersebut penulis melakukan langkahlangkah untuk memenuhi validitas sebagai berikut : a. menentukan tujuan mengadakan tes, yaitu untuk mendapatkan hasil belajar siswa; b. membuat pembatasan terhadap bahan yang akan diujikan.yaitu batasan mengenai materi pelajaran yang dituangkan dalam kisi-kisi soal tes, kisi-kisi soal tes siklus I dan kisi-kisi soal tes siklus II; c. menyusun butir-butir soal yang akan diujikan yang berbentuk essay. (Lampiran 5)

Data Hasil Observasi. Data yang didapat melalui lembar observasi yaitu gambaran peningkatan kreativitas belajar PPKn dengan menerapkan model pembelajaran project based learning. Cara penilaiannya diberi skor $1-4$ yaitu : tidak baik $=1$, kurang $=2$, cukup $=3$, baik $=4$ yang sesuai dengan penilaian pengamatan dalam proses pembelajaran kemudian dihitung rata-rata dan selanjutnya untuk setiap aspek tersebut dipersentasikan. Rata-rata diperoleh dari jumlah skor masing-masing aspek yang diamati dibagi dengan jumlah pertemuan. Kemudian data tersebut dianalisa dengan teknik persentase. Untuk mendapatkan persentase guru dalam mengelola pembelajaran, skor dari semua aspek dalam proses pembelajaran dihitung dengan rumus:

Persentase guru dalam mengelola pembelajaran $=$

$$
\frac{\text { Jumlah skor guru }}{\text { Skormaksimum }} \times 100 \%
$$

Jawaban yang diperoleh dijadikan dasar untuk mengambil kesimpulan kategori penilaian pelaksanaan pembelajaran dengan menerapkan model pembelajaran project based learning adalah :

\section{$76 \%-100 \%$ Baik$$
0 \%-25 \% \text { Tidak Baik }
$$$$
51 \%-75 \% \text { Cukup }
$$$$
26 \%-50 \% \text { Kurang }
$$

Data yang diperoleh dalam penelitian ini dianalisis dengan perhitungan persentase. Data diperoleh dari hasil tes tertulis, setelah data diperoleh dilakukan pengolahan data sebagai berikut: 1) Persentase ketuntasan belajar klasikal. Untuk melihat ketuntasan belajar, dilakukan dengan melihat penguasaan belajar siswa terhadap pokok bahasan yang dipelajari. Ketuntasan belajar diukur dengan menggunakan kriteria belajar yang tercantum dalam buku pedoman analisis hasil belajar Depdikbud (1994:6) yaitu: 1) Siswa dikatakan tuntas belajar jika siswa tersebut 
telah menguasai $65 \%$ dari materi yang diuji. 2) Siswa dikatakan tuntas secara klasikal jika $75 \%$ dari pengikut tes telah menguasai materi yang diajarkan.

$$
T B=\frac{s}{n} x 100 \%
$$

Dimana:

$T B=$ Tuntas belajar

$S=$ Jumlah yang memperoleh nilai lebih dari atau sama

dengan 6,5

$N=$ Jumlah Siswa

b) Nilai rata- rata

$$
\bar{x}=\frac{\sum x}{n}
$$

Dimana : $\quad \bar{x}=$ Nilai rata-rata siswa

$x=$ Nilai siswa

$n=$ Jumlah siswa

Data hasil belajar yang diperoleh dikatakan meningkat apabila hasil belajar yang diperoleh dari siklus II lebih tinggi (mencapai 75\% ) dari hasil belajar siklus I . Dimana pada penelitian ini peneliti menggunakan hasil tes ulangan harian sebagai titik awal untuk melihat peningkatan pada siklus pertama.

Indikator keberhasilan tindakan dalam penelitian ini dapat dilihat jika terdapat peningkatan kreativitas belajar siswa sebesar $80 \%$ dan hasil belajar siswa mencapai 75\% secara kualitatif dan kuantitatif.

\section{Hasil dan Pembahasan}

\section{Deskripsi Kondisi Awal (Pra Siklus)}

Mengingat penelitian tindakan ini penulis lakukan untuk mengetahui sejauh mana kreativitas dan hasil belajar siswa pada materi Proses pembentukan Peraturan Perundang-undangan mata Pelajaran PPKn dengan model project based learning,maka terlebih dahulu akan penulis paparkan hasil penga-matan belajar siswa sebelum siklus demi siklus dilakukan. Berdasarkan hasil pengamatan (observasi) yang telah dilakukan diperoleh gambaran bahwa kreativitas belajar siswa kelas VIII 2 SMPN 3 Koto Baru tergolong rendah.Dimana dari 26 orang siswa yang diamati 38,5\% siswa yang kreativ dan $61,5 \%$ belum kreativ .

Tabel 1. Presentase Kreativitas Belajar Siswa Kelas VIII.2 SMPN 3 Koto Baru pada Kondisi Awal

\begin{tabular}{|c|c|}
\hline Presentase siswa kreativ & Persentase siswa belum kreativ \\
\hline $38,5 \%$ & $61,5 \%$ \\
\hline
\end{tabular}

Dalam bentuk diagram seperti dibawah ini, 


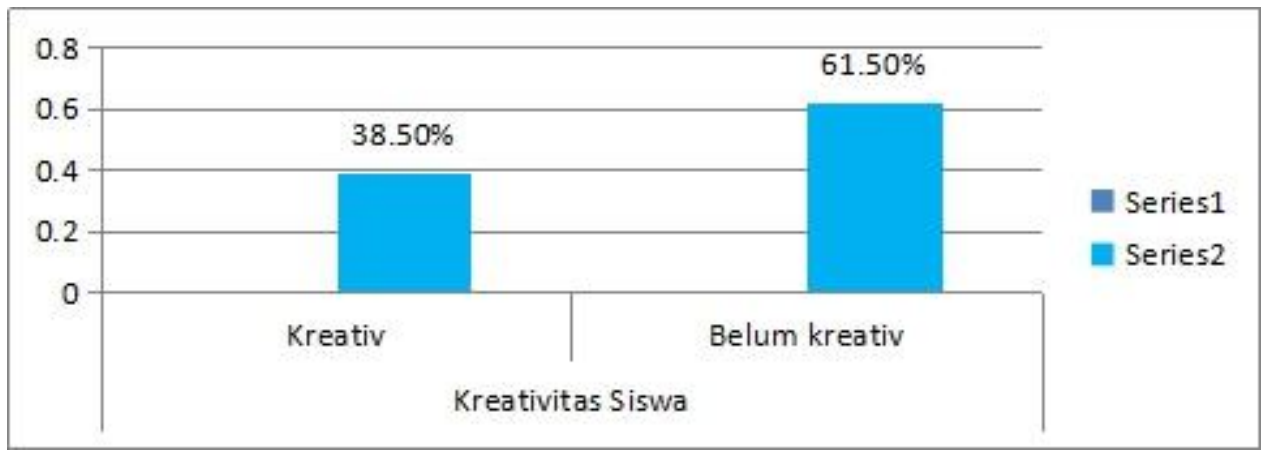

Diagram 1. Presentase Kreativitas Belajar Siswa Kelas VIII.2 SMPN 3 Koto Baru pada Kondisi Awal

Data hasil belajar siswa pada kondisi awal dapat dilihat pada tabel 2 berikut:

Tabel 2. Persentase Ketuntasan Hasil Belajar Kelas VIII.2 SMPN 3 Koto Baru pada Kondisi Awal/Pra Siklus

\begin{tabular}{|c|c|c|c|}
\hline No & Rentang Nilai & Tuntas & Tidak Tuntas \\
\hline 1 & $\leq 49$ & & 4 \\
\hline 2 & $50-59$ & & 9 \\
\hline 3 & $60-69$ & 6 & 7 \\
\hline 4 & $70-79$ & 0 & \\
\hline 5 & $80-89$ & 0 & \\
\hline 6 & $90-100$ & $\mathbf{6}$ & $\mathbf{2 0}$ \\
\hline & Jumlah & $\mathbf{2 3 , 1} \%$ & $\mathbf{7 6 , 9} \%$ \\
\hline
\end{tabular}

Jika digambarkan dengan menggunakan diagram,maka hasil belajar pada tahap awal yaitu sebagai berikut:

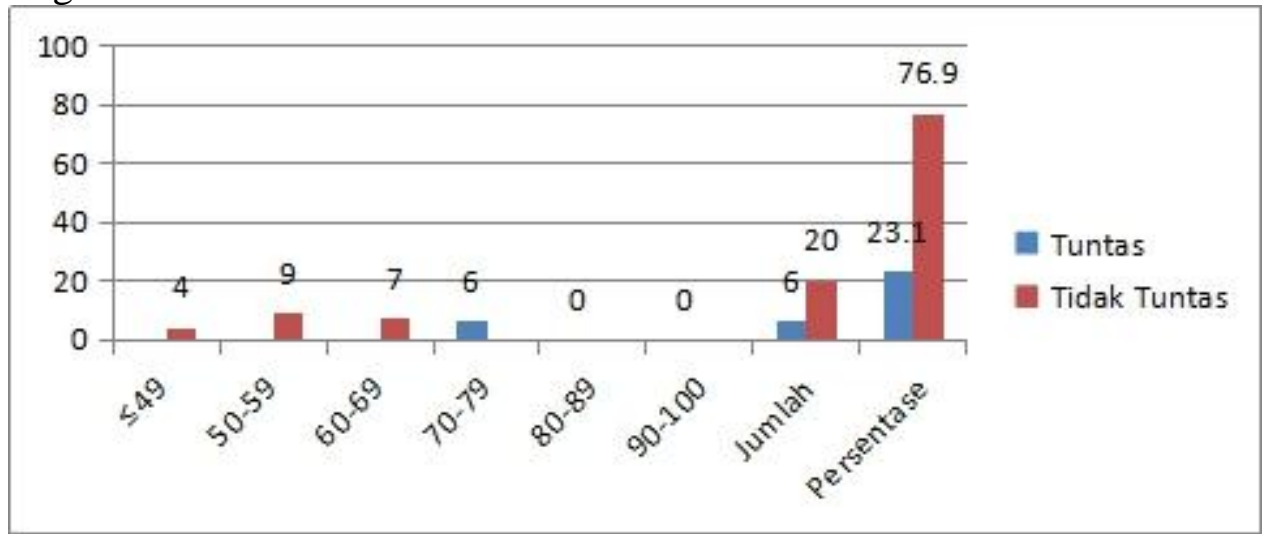

Diagram 2. Persentase Ketuntasan Hasil belajar siswa pada kondisi awal/Pra Siklus

Dari tabel dan diagram diatas 6 ( 23,1\%) siswa yang mencapai nilai Tuntas, 20 (76,9 \%) siswa yang belum mencapai KKM, dengan rincian nilai 60-69 berjumlah 7 
orang, 50-59 berjumlah 9 orang nilai $\leq 49$ berjumlah 4 orang, sedangkan siswa yang telah memenuhi KKM dengan nilai rentangan 70-79 berjumlah 6 orang. Rendahnya kreativitas belajar dan hasil belajar siswa tersebut disebabkan oleh kurang tertariknya siswa terhadap pembelajaran PPKn, sehingga guru perlu memberikan pembelajaran yang variatif, lebih kreativ dan bermakna bagi siswa.

\section{Hasil Penelitian Siklus I}

Hasil penelitian pada siklus I, berupa data yang memuat tingkat kreativitas belajar siswa selama 2 kali pertemuan dan satu jenis data hasil belajar siswa sebagai data pendukung penelitian yang diada-kan setelah penelitian siklus I berakhir.

1. Data kreativitas siswa belajar PPKn pada materi proses pembentukan UUD 1945 siklus I

Berdasarkan data hasil observasi proyek/tugas yang dibuat seluruh siswa setelah siklus I berakhir dapat dilihat pada Tabel 3 sebagai berikut :

Tabel 3. Persentase Kreativitas belajar PPKn melalui Model Project Based Learning Siswa Kelas VIII.2 SMPN 3 Koto Baru pada Siklus I

\begin{tabular}{|c|l|c|}
\hline No. & \multicolumn{1}{|c|}{ KREATIVITAS } & PERSENTASE \% \\
\hline 1. & Siswa mengerjakan tugas project & $56 \%$ \\
\hline 2. & $\begin{array}{l}\text { Kreativ dan inovatif dalam mengerjakan } \\
\text { tugas/project }\end{array}$ & $63 \%$ \\
\hline 3. & Membuat sendiri (keaslian) tugas /project & $67 \%$ \\
\hline 4. & Kebenaran tugas/project & $71 \%$ \\
\hline & Rata-Rata & $\mathbf{6 4 , 2 5 \%}$ \\
\hline
\end{tabular}

Pada Tabel 3 di atas menunjukkan rata-rata kreativitas siswa $64,25 \%$ belum memenuhi indikator pencapaian sebesar $\mathbf{8 0 \%}$. Kreativitas siswa tidak menyebar merata, sebagian besar siswa benar mengerjakan project yaitu $71 \%$, sebanyak $67 \% \%$ siswa membuat sendiri (keaslian ) tugas/project, untuk kreativ dan inovatf dalam mengerjakan tugas/project masih dibawah $80 \%$ hanya $63 \%$, sedangkan siswa mengerjakan tugas project hanya 56\% maka dapat dikatakan bahwa pada siklus I belum optimal dan oleh karena itu perlu ditingkatkan. Jika digambarkan dengan menggunakan diagram, maka hasil pengamatan di atas dapat dilihat pada diagram 3 yaitu sebagai berikut :

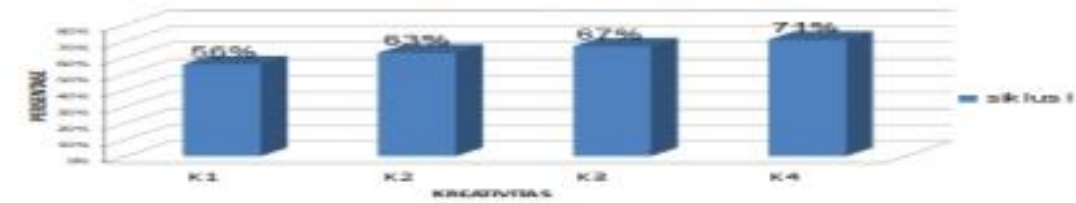

Diagram 3. Persentase Kreativitas belajar PPKn melalui Model Project Based Learning Siswa Kelas VIII.2 SMPN 3 Koto Baru pada Siklus I 
2 Data Hasil Belajar pada materi proses pembentukan UUD 1945 siklus I

Data hasil belajar siswa merupakan data pendukung pada penelitian tindakan kelas dengan rincian seperti pada Tabel.4 :

Tabel 4. Persentase Ketuntasan Hasil Belajar PPKn dengan model Project Based Learning Siswa Kelas VIII.2 SMPN 3 Koto Baru pada Akhir Siklus I

\begin{tabular}{|c|c|c|c|}
\hline No & Rentang Nilai & Tuntas & Tidak Tuntas \\
\hline 1 & $\leq 49$ & & 2 \\
\hline 2 & $50-59$ & & 3 \\
\hline 3 & $60-69$ & & 9 \\
\hline 4 & $70-79$ & 8 & \\
\hline 5 & $80-89$ & 3 & \\
\hline 6 & $90-100$ & 1 & $\mathbf{1 4}$ \\
\hline & Jumlah & $\mathbf{1 2}$ & $\mathbf{5 3 , 8} \%$ \\
\hline & Persentase & $\mathbf{4 6 , 2 \%}$ & \\
\hline
\end{tabular}

Dalam bentuk diagram seperti berikut ini,

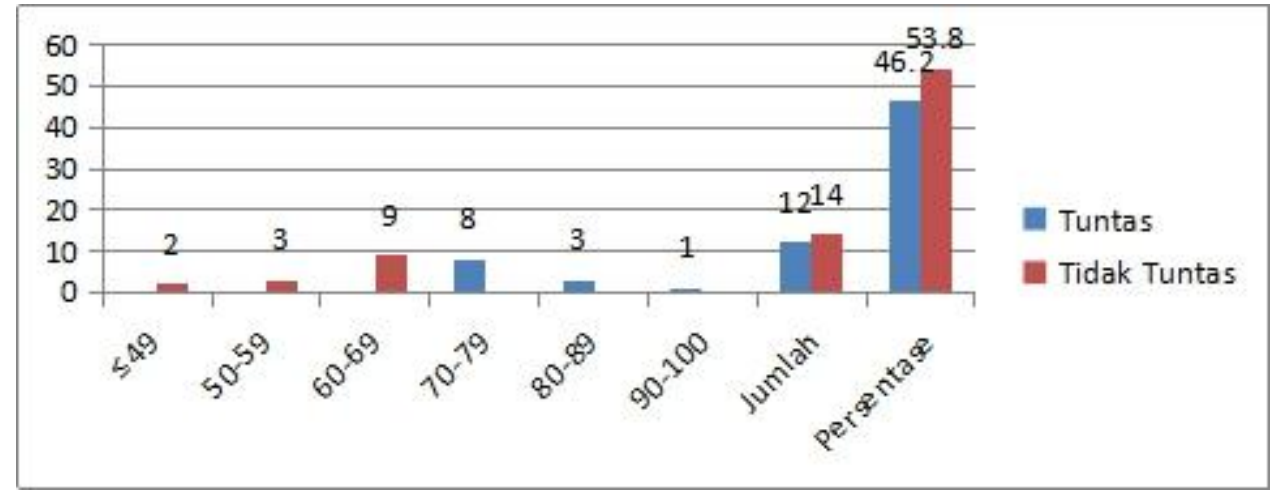

Diagram 4. Persentase Ketuntasan Hasil Belajar PPKn dengan model Project Based Learning Siswa Kelas VIII.2 SMPN 3 Koto Baru pada Akhir Siklus I

Dari tabel dan diagram 4 di atas menunjukkan hasil belajar siswa belum memenuhi indikator pencapaian $\mathbf{7 5 \%}$, persentase hasil belajar baru mencapai sebesar 46,2 \%. Nilai siswa tidak menyebar merata, sebagian besar berada pada kisaran 60-69 sebanyak 9 siswa, 70-99 sebanyak 8 siswa, maka dapat dikatakan bahwa pada siklus I belum optimal dan oleh karena itu perlu ditingkatkan.

\section{Refleksi Siklus I}

Berdasarkan hasil pengamatan dari pelaksanaan pembelajaran ditemukan hal-hal seperti di bawah ini: 1) Siswa kurang mempersiapkan diri belajar materi proses pembentukan peraturan perundang-undangan dan tidak berusaha mencari sendiri materi dari tugas awal serta kurang mengerti penjelasan guru di awal pembelajaran yang mengakibatkan mereka masih ada yang bingung mengerjakan tugas/proyek; 2) Sebagian besar siswa benar dalam mengerjakan proyek, hanya 63 persen siswa yang kreativ tapi ada juga siswa yang meniru dan meminta bantuan teman dalam mengerjakan proyek. Sebagian besar siswa sangat tertarik mengikuti sistem pembelajaran project based learning tapi ada juga yang tidak tertarik. 


\section{Hasil Penelitian Siklus II}

Pada siklus II, hasil penelitian yang diperoleh adalah sebagai berikut :

1. Data kreativitas siswa belajar PPKn pada materi proses pembentukan UndangUndang. Berdasarkan data hasil pengamatan pada seluruh siswa setelah siklus II berakhir dapat dilihat pada Tabel 5 sebagai berikut:

Tabel 5. Presentase Kreativitas Belajar Siswa Kelas VIII.2 SMPN 3 Koto Baru metode Project Based Learning pada siklus II

\begin{tabular}{|c|l|c|}
\hline No. & \multicolumn{1}{|c|}{ KREATIVITAS } & PERSENTASE \% \\
\hline 1. & Siswa mengerjakan tugas project & $82 \%$ \\
\hline 2. & $\begin{array}{l}\text { Kreativ dan inovatif dalam mengerjakan } \\
\text { tugas/project }\end{array}$ & $77 \%$ \\
\hline 3. & Membuat sendiri (keaslian) tugas /project & $90 \%$ \\
\hline 4. & Kebenaran tugas/project & $90 \%$ \\
\hline & Rata-Rata & $\mathbf{8 4 , 8}$ \\
\hline
\end{tabular}

Tabel 5 di atas menunjukkan bahwa rata-rata kreativitas belajar PPKn materi proses pembentukan peraturan perundang-undangan mengalami peningkatan menjadi $84,8 \%$ telah melampaui indikator pencapaian yang ditetapkan sebesar $80 \%$.

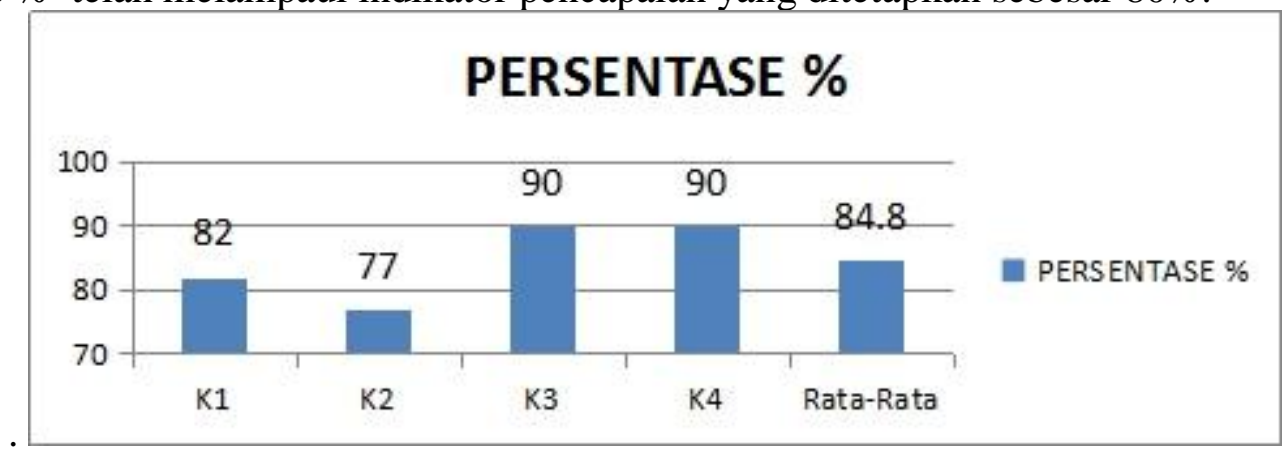

Diagram 5. Presentase Kreativitas Belajar Siswa Kelas VIII.2 SMPN 3 Koto Baru metode Project Based Learning pada siklus II

2. Data Hasil Belajar Siswa belajar PPKn pada materi proses pembentukan UndangUndang

Data hasil belajar siswa merupakan data pendukung pada penelitian tindakan kelas yang mengacu pada tingkat kreativitas belajar siswa dengan rincian seperti pada Tabel.6 :

Tabel 6. Persentase Ketuntasan Hasil Belajar PPKn dengan model Project Based Learning Siswa Kelas VIII.2 SMPN 3 Koto Baru pada Akhir Siklus II

\begin{tabular}{|c|c|c|c|}
\hline No & Rentang Nilai & Tuntas & Tidak Tuntas \\
\hline 1 & $\leq 49$ & & 0 \\
\hline 2 & $50-59$ & & 6 \\
\hline 3 & $60-69$ & & \\
\hline 4 & $70-79$ & 3 & \\
\hline 5 & $80-89$ & 15 & \\
\hline 6 & $90-100$ & 2 & \\
\hline
\end{tabular}




\begin{tabular}{|l|l|c|c|} 
& Jumlah & $\mathbf{2 0}$ & $\mathbf{7}$ \\
\hline & Persentase & $\mathbf{7 6 , 9}$ & $\mathbf{2 3 , 1}$ \\
\hline
\end{tabular}

Dalam bentuk diagram seperti berikut ini,

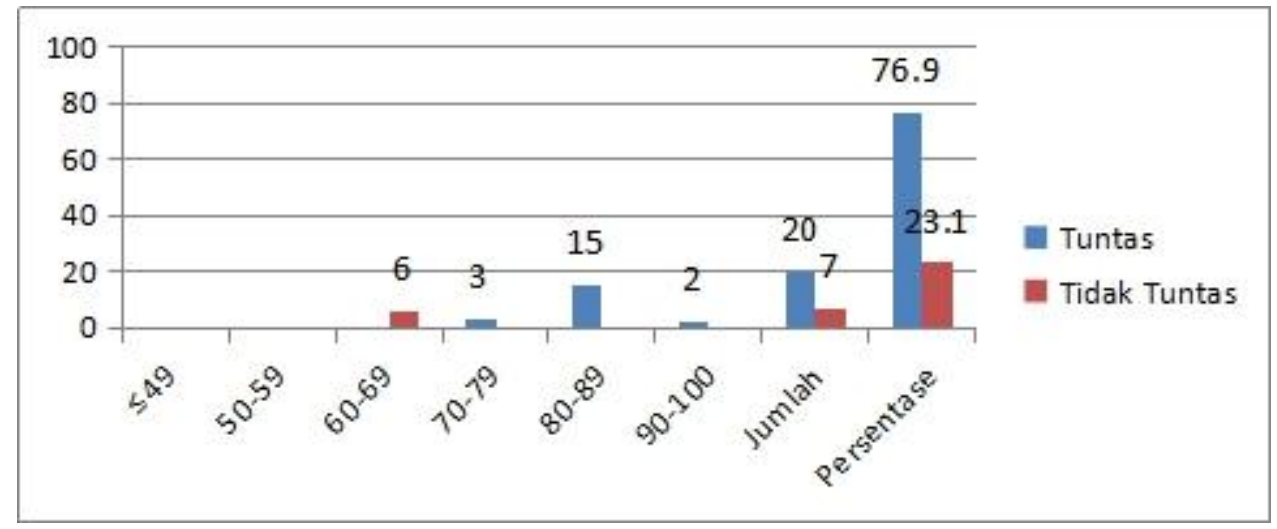

Diagram 6. Persentase Ketuntasan Hasil Belajar PPKn dengan model Project Based Learning Siswa Kelas VIII.2 SMPN 3 Koto Baru pada Akhir Siklus II

Pada diagram 6 di atas menunjukkan persentase ketuntasan klasikal sebesar 76,9 $\%$, hasil belajar siswa yang terbanyak berada pada nilai $80-89$, hasil belajar siswa telah melampaui target $75 \%$ penelitianpun tidak perlu dilanjutkan lagi.

\section{Refleksi Siklus II}

Secara umum kreativitas siswa belajar materi proses pembentukan peraturan perundang-undangan dengan menggunakan model pembelajaran Project based learning pada siklus II mengalami peningkatan dibanding siklus I. Pada siklus II ini tampak siswa mengalami peningkatan pemahaman materi yang dipelajari. Minat siswa belajar PPKn dengan model project based learning pun mengalami peningkatan.

Berdasarkan pengamatan terhadap kreativitas belajar materi proses pembentukan peraturan perundang-undangan, maka pada siklus II ditemui hal-hal sebagai berikut: 1) Sebagian siswa telah menyiapkan diri belajar materi proses pembentukan peraturan perundang-undangan dengan menggunakan model pembelajaran project based learning dengan kreativ dan inovatif; 2) Siswa sudah memahami project/tugas yang diberikan, sehingga keberlangsungan pembelajaran sesuai dengan rencana pelaksanaan pembelajaran; dan 3) Siswa meningkat pemahamannya terhadap materi proses pembentukan peraturan perundang-undangan nasional.

\section{Peningkatan Kreativitas siswa dari Siklus I ke Siklus II}

Proses pembelajaran yang sudah dilakukan, telah mengarah pada peningkatan kreativitas belajar siswa. Berdasarkan hasil pengamatan pada siklus I dan siklus II pada penelitian tindakan kelas ini, pembelajaran dengan model pembelajaran project based learning menunjukkan adanya peningkatan kreativitas siswa belajar materi proses pembentukan peraturan perundang-undangan pada masing-masing indikatornya. Secara rinci kenaikan indikator kreativ pada siklus II dapat dilihat pada Tabel.7 adalah sebagai berikut : 
Tabel 7. Peningkatan Kreativitas Belajar PPKn dengan Model Project Based Learning Siswa Kelas VIII.2 SMPN 3 Koto Baru pada Siklus I dan Siklus II

\begin{tabular}{|c|l|c|c|c|}
\hline No & \multicolumn{1}{|c|}{ KREATIVITAS } & $\begin{array}{c}\text { Siklus I } \\
\%\end{array}$ & $\begin{array}{c}\text { Siklus II } \\
\%\end{array}$ & $\begin{array}{c}\text { Peningkatan } \\
\%\end{array}$ \\
\hline 1 & Siswa mengerjakan tugas project & $56 \%$ & $82 \%$ & $26 \%$ \\
\hline 2 & $\begin{array}{l}\text { Kreativ dan inovatif dalam } \\
\text { mengerjakan tugas/project }\end{array}$ & $63 \%$ & $77 \%$ & $14 \%$ \\
\hline 3 & $\begin{array}{l}\text { Membuat sendiri (keaslian) tugas } \\
\text { /project }\end{array}$ & $67 \%$ & $90 \%$ & $23 \%$ \\
\hline 4 & Kebenaran tugas/project & $71 \%$ & $90 \%$ & $19 \%$ \\
\hline & Rata-rata & $\mathbf{6 4 , 3 \%}$ & $\mathbf{8 4 , 8 \%}$ & $\mathbf{2 0 , 5 \%}$ \\
\hline
\end{tabular}

Pada Tabel.7 dapat dilihat bahwa peningkatan kreativitas belajar siswa mengalami peningkatan yang cukup besar pada indikator siswa mengerjakan tugas project dan membuat sendiri (keaslian) tugas/project sebesar 23\%, kebenaran tugas/project sebesar 19\%, sedangkan kreativ dan inovatif dalam mengerjakan tugas/project sebesar $14 \%$, namun target pencapaian pada siklus II telah mencapai lebih dari $65 \%$. Jika dilihat dari rata-rata klasikal. Ini menunjukkan kelas dalam suasana yang mendukung sistem pembelajaran project based learning dan sesuai dengan rencana pelaksanaan pembelajaran, atau dapat dilihat dari Diagram.7 berikut:

Diagram 7. Persentase Peningkatan Kreativitas Belajar PPKn dengan Model Project Based Learning Siswa Kelas VIII.2 SMPN 3 Koto Baru pada Siklus I dan Siklus II

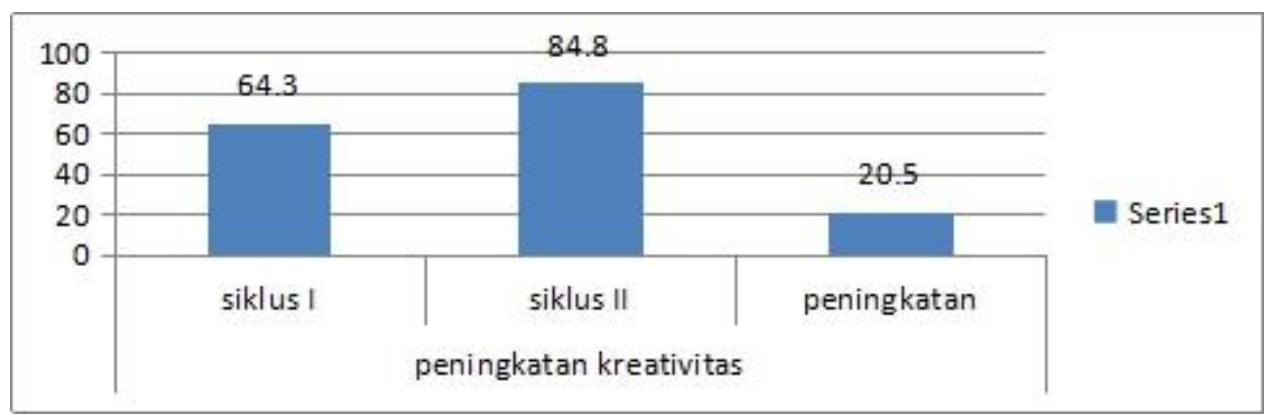

Pada diagram.7 di atas, menunjukkan bahwa kreativitas belajar PPKn melaui penerapan Project based learning mengalami peningkatan dari 64,3\% pada siklus I meningkat $84,8 \%$ pada siklus II, yang berarti terjadi peningkatan sebesar $20,5 \%$.

\section{Peningkatan Hasil Belajar Siswa Akhir Siklus I dan Siklus II}

Hasil Belajar siswa dan persentasi ketuntasan klasikal pada siklus I dan Siklus II dapat dilihat pada Tabel. 8 sebagai berikut :

Tabel 8. Persentase Ketuntasan Hasil Belajar PPKn dengan Model Project Based

Learning Siswa Kelas VIII.2 SMPN 3 Koto Baru pada Siklus I dan Siklus II

\begin{tabular}{|l|c|c|}
\hline \multicolumn{1}{|c|}{ Hasil Belajar } & Jumlah siswa yang tuntas & $\%$ Ketuntasan \\
\hline Siklus I & 12 & 46,2 \\
\hline Siklus II & 20 & 76,9 \\
\hline Peningkatan & 8 & 30,7 \\
\hline
\end{tabular}

Pada Tabel.8 dapat dilihat peningkatan jumlah siswa yang mencapai KKM dari 12 siswa pada siklus I meingkat menjadi 20 orang pada siklus II artinya bertambah 8 orang, sedangkan persentase ketuntasan dari 46,2\% pada siklus I meningkat menjadi 
$76.9 \%$ pada siklus II yang berarti terjadi peningkatan $30,7 \%$. Peningkatan hasil belajar yang terjadi dikarenakan adanya penelusuran proses pembelajaran tetap sesuai dengan rencana pelaksanaan yang berbasis pada model pembelajaran project based learning, dengan mengecek kembali kelemahan-kelemahan yang dialami peserta didik dalam proses pembelajaran sebelumnya. Peningkatan masing-masingnya dapat dengan jelas dilihat pada Diagram. 8 berikut :

Diagram 8. Persentase Ketuntasan Hasil Belajar PPKn dengan Model Project Based

Learning Siswa Kelas VIII.2 SMPN 3 Koto Baru pada Siklus I dan Siklus II

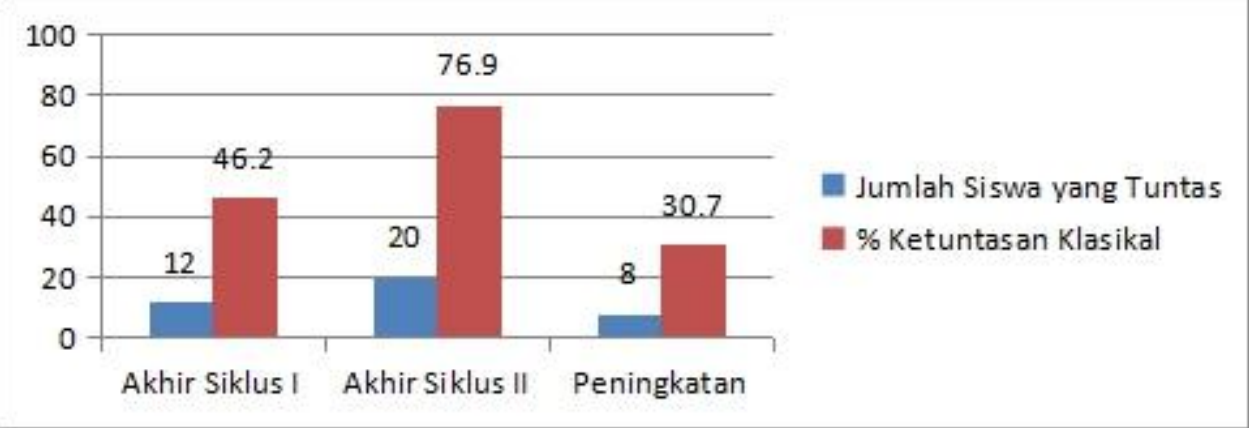

Meningkatnya pemahaman, ketekunan, keuletan minat dan kemandirian siswa dalam belajar materi proses pembentukan peraturan perundang-undangan memungkinkan karena proses pembelajaran yang berlangsung dengan menggunakan model pembelajaran project based learning, walaupun hasil belajar yang diperoleh tidak begitu mendekati nilai optimal $100 \%$ tuntas namun telah melampaui target yang ditetapkan dalam penelitian ini.

\section{Penutup}

Berdasarkan temuan hasil penelitian tindakan kelas dapat ditarik kesimpulan : "Jika pada siswa kelas VIII 2 SMPN 3 Koto Baru Dharmasraya dilakukan proses pembelajaran dengan menggunakan Model pembelajaran project based learning maka akan terjadi peningkatan kreativitas dari 38,50\% pada pra siklus, meningkat $64,25 \%$ Siklus I dan meningkat lagi $84,8 \%$ pada siklus II , sedangkan hasil belajar dari $23,1 \%$ pada pra siklus, meningkat $46,2 \%$ siklus I dan meningkat lagi $76,9 \%$ pada siklus II PPKn”. Untuk menyempurnakan hasil yang diperoleh dalam penelitian ini maka diajukan saran sebagai berikut : 1) Perlu dilakukan penelitian lanjutan untuk kelas yang sama atau berbeda dengan materi yang berbeda atau sama guna menghasilkan hasil yang lebih optimal, 2) dalam penerapan project based learning untuk meningkatkan kreativitas dan hasil belajar pada mata pelajaran PPKn , perlu dibimbing oleh guru agar hasil belajar siswa meningkat, 3) perlu dilakukan pemantauan yang lebih banyak sehingga siswa mempunyai kesempatan untuk bertanya hal-hal yang tidak atau belum mereka mengerti selama proses pembelajaran berlangsung, 4) bagi siswa yang terlibat dalam penelitian ini agar tetap menanamkan sikap positif dalam pembelajaran PPKn yaitu kreativ,inovatif, menjalin kerjasama yang baik, dan bersemangat dalam belajar.

\section{Daftar Pustaka}

Azizah, Nur.(2009).Penelitian Tindakan Kelas.Dharmasraya.

Depdikbud. 1994. Kurikulum Pendidikan Dasar (GBPP). Depdikbud .Jakarta.

Dimyati dan Mudjiono. 2009. Belajar dan Pembelajaran. Jakarta: PT. Rineka Cipta. 
Kamdi. 2007. Strategi Pembelajaran. Bandung:PT Remaja Rosdakarya.

Kemdikbud. 2013. Model Pengembangan Berbasis Proyek (Project Based Learning).(Online), (http://www.eurekapendidikan.com/s.

Kemendikbud. (2014). Peraturan Menteri Pendidikan dan Kebudayaan, Nomor 58, Tahun 2014, tentang Kurikulum 2013 (SMP) / Madrasah Tsanawiyah (MTs).

Munandar, Utami. (1992:47). Mengembangkan bakat dan kreativitas. Jakarta: Grasindo.

Nana Sudjana 2010. Dasar-dasar Proses Belajar, Sinar Baru Bandung

Nuzan dalam,https://nuzan.wordpress.com/2012/07/21/pengertian-pbl-project-basedlearning.

Supriyadi, D. 1994. Kreativitas, Kebudayaan \& Perkembangan IPTEK. Bandung: Alfabeta 